\title{
1 Terrestrial evidence for the Lilliput effect across the Cretaceous-Paleogene
}

\section{2 (K-Pg) boundary}

3

4 Logan A. Wiest ${ }^{\text {a,b*, }}$, William E. Lukens ${ }^{\text {a }}$, Daniel J. Peppe ${ }^{\text {a }}$, Steven G. Driese ${ }^{\text {a }}$, Jack Tubbs ${ }^{\mathrm{c}}$

5

$6 \quad{ }^{a}$ Terrestrial Paleoclimatology Research Group, Department of Geosciences, One Bear Place

$7 \quad$ \#97354, Baylor University, Waco, TX 76798, U.S.A.

$8 \quad \mathrm{~b}$ Institute of Archaeology, One Bear Place \#97173 Baylor University, Waco, TX 76798, U.S.A.

$9 \quad{ }^{\mathrm{c}}$ Department of Statistical Science, One Bear Place \#97140 Baylor University, Waco, TX 76798, 10 U.S.A.

11 *E-mail: Logan_Wiest@baylor.edu

12

13 Highlights:

14

21 Keywords: Naktodemasis bowni; mass extinction; dwarfism; Big Bend National Park;

22 subterranean insects 
Wiest, L.A., Lukens, W.E., Peppe, D.J., Driese, S.G., and Tubbs, J., (in press), Terrestrial evidence for the Lilliput effect across the Cretaceous-Paleogene (K-Pg) boundary, Palaeogeography, Palaeoclimatology,

Palaeoecology. PREPRINT. DOI 10.17605/OSF.IO/9X7DU

23 Abstract

24 Recent research has demonstrated that the Lilliput effect (reduction of body size in biota associated with the aftermath of mass extinctions) affected all trophic levels in the marine realm

26 following the Cretaceous-Paleogene (K-Pg) event. However, it is unclear if this size change was

27 strictly a marine signal, or a global phenomenon that also affected continental ecosystems.

28 Herein we present the results of an ichnological proxy for body size of soil-dwelling insects across the K-Pg boundary in Big Bend National Park, Texas, U.S.A. Quantitative efforts focused on Naktodemasis bowni, which are characterized as unbranching burrows composed of ellipsoidal packets of backfill menisci. These traces were likely produced by beetle larvae or

32 cicada nymphs based on previous comparison with structures generated in modern soils and 33 laboratory experiments. As an approximation for the body size of the subterranean insects, this 34 dataset indicates that a smaller $N$. bowni diameter $\left(\mathrm{D}_{N}\right)$ is statistically correlated $(\alpha<0.05)$ with 35 several edaphic factors including poor soil drainage and weak soil development (Entisols). Additionally, the $\mathrm{D}_{N}$ in strata immediately superjacent to the highest Cretaceous-specific taxa is

37 smaller by $23 \%(5.6 \pm 1.8 \mathrm{~mm})$ in comparison to $\mathrm{D}_{N}$ within the subjacent Cretaceous interval $(7.3$

$38 \pm 2.7 \mathrm{~mm})$. This abrupt shift occurs in a well-drained Inceptisol, and cannot be attributed to

39 facies changes, drainage, or paleosol maturity. Furthermore, a reduced $\mathrm{D}_{N}(6.6 \pm 2.3 \mathrm{~mm})$

40 persists above this anomalous shift for at least 20 stratigraphic meters within chron $29 \mathrm{r}$. The

41 cause for this negative response in body size within soil-dwelling biota may be attributed to

42 plant-community shifts in taxonomic composition and ecological strategies, which would have

43 caused fundamental alterations to the diet of the herbivorous, subterranean insects. This study

44 provides empirical evidence that the Lilliput effect was not restricted to marine environments

45 during the aftermath of the K-Pg event. 
Wiest, L.A., Lukens, W.E., Peppe, D.J., Driese, S.G., and Tubbs, J., (in press), Terrestrial evidence for the Lilliput effect across the Cretaceous-Paleogene (K-Pg) boundary, Palaeogeography, Palaeoclimatology,

Palaeoecology. PREPRINT. DOI 10.17605/OSF.IO/9X7DU

\section{Introduction}

Recent studies have demonstrated that planktic foraminifera (Keller and Abramovich 2009), coccolithophores (Gardin and Monechi 1998), marine mollusks and vermiform organisms (Gallagher 1990; Aberhan et al. 2007; Łaska et al. 2017), decapod crustaceans (Wiest et al. 2015, 2016; Martínez-Díaz et al. 2016, 2017; Łaska et al. 2017), and lamniform sharks (Belben et al. 2017) experienced a reduction in body size during the aftermath of the Cretaceous-Paleogene (KPg) extinction event. Importantly, this reveals that the Lilliput effect (c.f. Twitchett 2007; Harries and Knorr 2009) occurred at all trophic levels in the marine realm. In this study, the term "Lilliput effect" refers to extinction selectivity for small sizes (phyletic dwarfism), and also small-sized organisms preferentially surviving the extinction event and replacing the larger-sized clades. Changes in body size provide insight into the response of organisms to large-scale environmental perturbations operating in ancient ecosystems, and understanding the magnitude and extent of this phenomenon from past events may help constrain predictions for current biodiversity loss (Bottjer and Droser 1994; Morrow and Hasiotis 2007; Sheridan and Bickford 2011; Cheung et al. 2013).

It remains uncertain if the Lilliput effect following the K-Pg event was strictly a marine signal, or a broader phenomenon that also affected continental ecosystems. This study focuses on terrestrial ichnotaxa preserved in paleosols. These traces formed in situ, are well-preserved, and are sensitive metrics of subterranean-organism biology and behavior, and environmental conditions (Bown and Kraus 1983; Hasiotis and Bown 1992; Hasiotis 2002; Rodríguez-Tovar 2007; Smith et al. 2009; Wiest and Buynevich 2015; Hembree and Blair 2016; Genise 2017).

Furthermore, soils have been hypothesized as refugia for terrestrial organisms during the widespread environmental disturbance associated with the K-Pg event (Harries et al. 1996; 
Wiest, L.A., Lukens, W.E., Peppe, D.J., Driese, S.G., and Tubbs, J., (in press), Terrestrial evidence for the Lilliput effect across the Cretaceous-Paleogene (K-Pg) boundary, Palaeogeography, Palaeoclimatology,

Palaeoecology. PREPRINT. DOI 10.17605/OSF.IO/9X7DU

Robertson et al. 2004; Bardeen et al. 2017). The response of soil-dwelling invertebrates to environmental disturbance may serve as a proxy for overall ecosystem health across the K-Pg interval because these organisms inhabit low trophic levels.

Herein we report the results of a quantitative ichnological study that reveals an abrupt and persistent reduction in body size within the soil-dwelling community across the K-Pg boundary from Big Bend National Park, Texas, U.S.A. This dataset provides empirical evidence that the Lilliput effect also occurred in terrestrial settings during the aftermath of the K-Pg mass extinction, and implies that burrowing insects were also substantially affected by the event.

\section{Geological setting}

The Upper Cretaceous (Maastrichtian) and Paleocene (Danian) strata within the Dawson Creek section of Big Bend National Park, Brewster County, Texas, U.S.A., consist of southwestward-dipping channel sandstone bodies, fine-grained fluvial overbank deposits, and associated paleosols (Fig. 1; Lehman 1985, 1990, 1991; Atchley et al. 2004). The Dawson Creek exposure within the Tornillo Basin is an extensively studied continental K-Pg section in the southwestern United States. The framework of this particular set of outcrops includes biostratigraphy (Wilson 1970; Schiebout 1974; Standhardt 1986; Schiebout et al. 1987; Lehman 1991), magnetostratigraphy (Rapp et al. 1983; Leslie et al. 2015, accepted), terrestrial sequence stratigraphy (Atchley et al. 2004), paleopedology (Nordt et al. 2003, 2011), and paleoenvironmental reconstruction (Lehman 1990). Previous studies of the paleosols occurring throughout the stratigraphic succession suggested that paleoclimate conditions were subhumid to semiarid, vegetation was predominantly dry woodland, and the paleosols resemble modern Entisols, Inceptisols, and Vertisols (Atchley et al. 2004; Nordt et al. 2011). Of particular note 
Wiest, L.A., Lukens, W.E., Peppe, D.J., Driese, S.G., and Tubbs, J., (in press), Terrestrial evidence for the Lilliput effect across the Cretaceous-Paleogene (K-Pg) boundary, Palaeogeography, Palaeoclimatology,

Palaeoecology. PREPRINT. DOI 10.17605/OSF.IO/9X7DU

92 was the documentation of two greenhouse events preceding the K-Pg impact, based on analysis

93 of stable isotopes of pedogenic carbonates from the Dawson Creek section (Nordt et al. 2003).

Our analysis focused on the stratigraphic interval that includes the Upper Cretaceous

95 Javelina Formation, as well as the lowermost Paleocene Black Peaks Formation (Fig. 2). The

96 formational contact between the Javelina and Black Peaks is conformable (Lehman, 1990),

97 occurs within chron 29r (Leslie et al. accepted), and has been interpreted to represent the K-Pg

98 boundary (e.g., Lehman 1990; Nordt et al. 2003, 2011), although there remains an apparent

99 absence of diagnostic impact indicators such as shocked minerals, impact-derived spherules, or

100 geochemical anomalies (e.g., iridium), nor have there been recovered identifiable palynomorphs.

101 The highest Cretaceous-specific remains recovered from this section are disarticulated

102 Quetzalcoatlus (Pterosauria, Azhdarchidae) from a fluvial body between paleosol 21 (P21) and

103 P22 within the Javelina Formation (Fig. 2; Lawson 1972, 1975; Lehman 1990). Paleocene

104 mammals occur within the Black Peaks Formation at $20 \mathrm{~m}$ above the last occurrence of

105 Cretaceous fossils in a channel complex (superjacent to P28) that is interpreted to be

106 unconformable at its base (Atchley et al. 2004; Lehman and Busby 2007; Leslie et al. 2015;

107 Cobb 2016). Reanalysis of the Black Peaks mammalian faunas, coupled with revised

108 magnetostratigraphy for the section, indicate that the mammals occur within the Torrejonian

109 North American Land Mammal Age and were deposited in chron 27r (Leslie et al. accepted).

111 3. Methods

A series of field excursions were conducted within Big Bend National Park during the

113 spring and fall of 2015. All field activities complied with U.S. National Park Service regulations.

114 Individual stratigraphic units and paleosols documented in Nordt et al. $(2003,2011)$ and in 
Wiest, L.A., Lukens, W.E., Peppe, D.J., Driese, S.G., and Tubbs, J., (in press), Terrestrial evidence for the Lilliput effect across the Cretaceous-Paleogene (K-Pg) boundary, Palaeogeography, Palaeoclimatology,

Palaeoecology. PREPRINT. DOI 10.17605/OSF.IO/9X7DU

115

116

117

118

119

120

121

122

123

124

125

126 127 horizons.

128

129

130

131

132

133

134

135

136

137

Atchley et al. (2004) were located via GPS coordinates in conjunction with photomosaics labeled with stratal surfaces and paleosols tops, which were generated in the field with a laptop during 2002 (S. Atchley, pers. comm. 2015). Assignment of stratigraphic position in meters, paleosol nomenclature, facies associations, and drainage parameters were adapted from Atchley et al. (2004; cf. their Fig. 3). Paleosol drainage was characterized by Atchley et al. (2004) based on matrix color, where poorly drained paleosols were gray to blue-gray, moderately drained paleosols were yellow or brown, and well-drained paleosols were red to purple. Accordingly, these drainage indices were easily confirmed in the field. Interpretations of paleosol taxonomic order assigned by Atchley et al. (2004) followed USDA-NRCS soil taxonomy and were crosschecked in the field based on paleosol morphology and horizonation. Entisols were typically stacked A-C horizons without subsurface B horizon development, Inceptisols had weakly developed B horizons (typically Bw), and Vertisols contained pedogenic slickensides in Bss

Multiple, laterally distributed, fresh excavation surfaces within each sedimentary unit were examined in the field for biogenic structures (plant and animal). Trace fossils were described based on surficial and architectural morphology, dimensions, and burrow fill. The depth of maximum bioturbation was determined with a measuring tape for each paleosol. The minimum inner diameters of shafts and tunnels of each trace observed were measured with a digital caliper to the nearest $0.1 \mathrm{~mm}$, except for root traces, which were distinguished by their characteristic tapering and bifurcation (Retallack 1988; Driese et al. 1997; Elick et al. 1998). A semiquantitative ichnofabric index was used to characterize the degree of bioturbation where $1=$ no bioturbation; $2=$ discrete, isolated burrows; $3=10-40 \%$ of bedding is disturbed; $4=$ nearly complete bioturbation; and 5 = complete bioturbation (Droser and Bottjer 1986; Genise et al. 
Wiest, L.A., Lukens, W.E., Peppe, D.J., Driese, S.G., and Tubbs, J., (in press), Terrestrial evidence for the Lilliput effect across the Cretaceous-Paleogene (K-Pg) boundary, Palaeogeography, Palaeoclimatology,

Palaeoecology. PREPRINT. DOI 10.17605/OSF.IO/9X7DU only clay or well-sorted sand (Fig. 2).

\section{Results}

\subsection{Naktodemasis morphology}

2004). Burrow diameters were evaluated using the nonparametric Wilcoxon/Kruskal-Wallis Test for mean ranks, with post-hoc analyses using Tukey's honest significant difference (HSD) to test for directionality in mean sizes using JMP (v.13) statistical software.

Celliforma isp. (capsule-shaped, smooth cells) and Skolithos isp. (vertical cylindrical tubes) occur in Cretaceous portions of the study interval, but quantitative analysis, instead, focused on Naktodemasis bowni, also referred to as adhesive meniscate burrows (Smith and Hasiotis 2008; Smith et al. 2008; Counts and Hasiotis 2009), due to the pervasiveness of this structure throughout the section and occurrence in both Cretaceous and Paleocene strata (Fig. 3).

The $N$. bowni observed from the Dawson Creek section are characterized as unlined, unbranching burrows composed of packets of densely spaced meniscate backfill. The traces do not differentially weather from the outcrop or exhibit any relief, but are otherwise apparent on freshly broken ped surfaces because of differences in menisci color in comparison to host matrix (Fig. 3). Traces are readily visible in areas of the paleosols that do not have a homogenous color. Burrows are generally straight, and are highly variable in orientation, ranging from vertical to horizontal. True branching was not observed; however, burrows commonly overlap each other in intensely bioturbated intervals and seldom generate what appears to be false branching. $N$. bowni were only observed in fine-grained mudrocks, and were not found in lithologies composed of 
Wiest, L.A., Lukens, W.E., Peppe, D.J., Driese, S.G., and Tubbs, J., (in press), Terrestrial evidence for the Lilliput effect across the Cretaceous-Paleogene (K-Pg) boundary, Palaeogeography, Palaeoclimatology,

Palaeoecology. PREPRINT. DOI 10.17605/OSF.IO/9X7DU

\subsection{Naktodemasis bowni size and edaphic controls}

In total, 808 inner diameters of $N$. bowni $\left(\mathrm{D}_{N}\right)$ were measured from 15 paleosols distributed over approximately $85 \mathrm{~m}$ of stratigraphic section (Fig. 4). Summary statistics for $\mathrm{D}_{N}$ are presented in Table 1; all measured $\mathrm{D}_{N}$ and associated paleosol characteristics are reported in Supplemental Data Table A1. Where possible, a minimum of 35 measurements of $\mathrm{D}_{N}$ was acquired for each paleosol.

The abundance of $\mathrm{D}_{N}$ in each paleosol was characterized using ichnofabric index (Droser and Bottjer 1986). Whereas differences were observed between ichnofabric index (ii) categories, $\mathrm{D}_{N}$ decreases in a non-sequential order of $\mathrm{ii}=4,2,5$, and 3. Ichnofabric index values are not homogeneous across categories of stratigraphic age (K vs. Pg), drainage, soil order, or paleosol number (chi-square, $\mathrm{p}<0.001$ for each). Drainage conditions are a significant predictor of ichnofabric index, with more well-drained paleosols tending to have a higher ichnofabric index value (Fig. 2). The distribution of ichnofabric index values varies across the measured section the base of the section generally has lower ichnofabric index values, on average, and a series of high ii values (5) were observed only in P23 and P24 (Fig. 2). Regardless of this, the number of measured $\mathrm{D}_{N}$ per paleosol is not correlated with mean $(\mathrm{F}$-test, $\mathrm{p}=0.56)$ or median $(\mathrm{p}=0.63) \mathrm{D}_{N}$. Poorly-drained paleosols contain $\mathrm{D}_{N}$ significantly different than both moderately drained and well-drained paleosols ( $\mathrm{p}<0.01$ for both); whereas there is no significant difference in $\mathrm{D}_{N}$ between moderately and well-drained paleosols $(\mathrm{p}=0.8)$. Tukey's HSD run post-hoc demonstrates that $\mathrm{D}_{N}$ within poorly drained paleosols is smaller than those occurring in moderately and well-drained paleosols ( $\mathrm{p}<0.05$ for both). 
Wiest, L.A., Lukens, W.E., Peppe, D.J., Driese, S.G., and Tubbs, J., (in press), Terrestrial evidence for the Lilliput effect across the Cretaceous-Paleogene (K-Pg) boundary, Palaeogeography, Palaeoclimatology,

Palaeoecology. PREPRINT. DOI 10.17605/OSF.IO/9X7DU

Finally, $\mathrm{D}_{N}$ is significantly different in Entisols compared to both Inceptisols $(\mathrm{p}<0.001)$ and Vertisols $(\mathrm{p}<0.01)$. Tukey's HSD indicates that $\mathrm{D}_{N}$ is smaller in Entisols than in Inceptisols $(\mathrm{p}<0.001)$ and Vertisols $(\mathrm{p}<0.05)$.

The population of $N$. bowni from the interval below P22, which is known to be of Cretaceous in age, contains $\mathrm{D}_{N}$ significantly different than those above the highest known Cretaceous vertebrate fossil (P22 and above; $\mathrm{p}<0.001$ ), regardless of paleosol type or drainage. Tukey's HSD run post-hoc indicates that the population above the Cretaceous taxa have smaller $\mathrm{D}_{N}$ than those within the Cretaceous interval $(\mathrm{p}<0.001)$.

\section{Discussion}

\subsection{Ethology of the tracemakers}

The $N$. bowni are most similar to traces produced by such extant soil-dwelling insects as burrower bugs (Hemiptera: Cydnidae), cicada nymphs (Hemiptera: Cicadidae), and beetle larvae (Coleoptera: Scarabaeidae) in modern soils and laboratory experiments (Marlatt 1907; Smith and Hasiotis 2008; Smith et al. 2008; Counts and Hasiotis 2009). Beetles (Coleoptera) occur occasionally during the Permian, and cicadas (Cicadoidea) and have been recovered from as early as the Triassic, but it remains a possibility that other burrowing insects with similar body plans and behaviors were capable of producing these traces (Lefebvre et al. 1998; Rasnitsyn and Quicke 2002; Grimaldi and Engel 2005; Feng et al. 2017). Subterranean nymphs and larvae of certain extant species of cicadas and beetles, respectively, burrow through the soil to feed on the xylem sap of plant roots, living plant roots, and disseminated soil organic matter (White and Strehl 1978; Tashiro 1987). Smith and Hasiotis (2008) and Counts and Hasiotis (2009) demonstrated through laboratory experiments that $N$. bowni were generated as an open, elongate 
Wiest, L.A., Lukens, W.E., Peppe, D.J., Driese, S.G., and Tubbs, J., (in press), Terrestrial evidence for the Lilliput effect across the Cretaceous-Paleogene (K-Pg) boundary, Palaeogeography, Palaeoclimatology,

Palaeoecology. PREPRINT. DOI 10.17605/OSF.IO/9X7DU

205 or ovoid cell that was continuously moved forward as the tracemaker repeatedly removed

206 material from the front of the cell, rotated to transport the sediment, and packed the material in

207 the back of the cell.

208

209

5.2 Mechanisms for reduced body size of soil-dwelling fauna

Trends in $\mathrm{D}_{N}$, similar to the results reported herein, have been previously documented

across the Paleocene-Eocene Thermal Maximum (PETM) in paleosols similar to those within the

212 Dawson Creek section from Big Bend National Park. The reduction in trace-fossil size generated

213 by soil-dwelling insects was attributed to 1) drier floodplain conditions (lower soil moisture), 2)

214 higher surface temperatures, or 3) vegetation (food source) with diminished nutritional value due

215 to elevated atmospheric $\mathrm{CO}_{2}$ (see Smith et al. 2009 and references therein).

Whereas drier soil conditions have been correlated with smaller $\mathrm{D}_{N}$ across the PETM

217 interval and in some species of extant dung beetles (Vessby 2001), a reduction in soil moisture is

218 an improbable forcing mechanism for the K-Pg trend observed in Big Bend for multiple reasons.

219 First, as mentioned previously, larger $\mathrm{D}_{N}$ were observed in well-drained paleosols compared to

220 poorly drained conditions (Table 1). Second, soil drainage does not appear to change

221 systematically from the Upper Cretaceous through the lower Paleocene (Atchley et al. 2004).

222 Finally, paleosols in the Dawson Creek section generally have deeper carbonate horizons and

223 less weatherable base oxides up-section, suggesting that the climate gradually became wetter

224 during the early Paleocene, but not coincident with the proposed extinction interval between P21

225 and P22 (Lehman 1990; Nordt et al. 2011). These observations indicate that edaphic and climatic

226 variables are not dominant factors in the dramatic and persistent decrease in $\mathrm{D}_{N}$ that begins in

$227 \quad$ P22. 
Wiest, L.A., Lukens, W.E., Peppe, D.J., Driese, S.G., and Tubbs, J., (in press), Terrestrial evidence for the Lilliput effect across the Cretaceous-Paleogene (K-Pg) boundary, Palaeogeography, Palaeoclimatology,

Palaeoecology. PREPRINT. DOI 10.17605/OSF.IO/9X7DU

The Late Maastrichtian Event (LME), which is a transient episode of increased

229

230

231

232

233

234

235

236

237

238

239

240

241

242

243

244

245

246

247

248

249

atmospheric $\mathrm{CO}_{2}$ and surface temperature just below the K-Pg boundary, has been previously

identified at this same outcrop succession based on paleosol proxies (Nordt et al. 2003). The $\mathrm{CO}_{2}$

and warming spike was observed in P19 (Fig. 2; Nordt et al. 2003). P19 also contains abundant

$N$. bowni and therefore presents an opportunity to assess the correlation between $p \mathrm{CO}_{2}$, increased

surface temperatures, and $\mathrm{D}_{N}$ (Fajer et al. 1989; Atkinson 1994; Sibly and Atkinson 1994;

Parmesan 2006). Surprisingly, we found no evidence of a change in $\mathrm{D}_{N}$ over the interval of

elevated $p \mathrm{CO}_{2}$ and temperature reported in Nordt et al. (2003). Given the assumption that active

pedogenesis of P19 occurred during a time of intensified greenhouse conditions, and that P23-

P28 were developed during a relatively cooler period (Nordt et al. 2003, their Fig. 3), it is

improbable that increased temperature is a driving mechanism for the negative response in $\mathrm{D}_{N}$

for this dataset.

The biogeochemistry of paleosols throughout the Dawson Creek section was

reconstructed by Nordt et al. (2011), which provided results pertinent to our study. First, there is

no observed change in overall soil quality or biogeochemical function in the paleosols across our study interval. The paleosols were generally nutrient-rich, had relatively high-water holding capacity, and ranged from circumneutral to alkaline $\mathrm{pH}$. Accordingly, no evidence exists for aluminum or sodium toxicity, which can occur at extreme low and high $\mathrm{pH}$, respectively, and limit nutrient availability in soils (Delhaize and Ryan 1995; Beyrouty et al. 2000; Qadir and Schubert 2002). Taken together, there were no systematic changes in possible edaphic controls for the habitability of the paleosols in the section, therefore, forcing mechanisms external to the substrate must account for the observed overall up-section reduction in $\mathrm{D}_{N}$. 
Wiest, L.A., Lukens, W.E., Peppe, D.J., Driese, S.G., and Tubbs, J., (in press), Terrestrial evidence for the Lilliput effect across the Cretaceous-Paleogene (K-Pg) boundary, Palaeogeography, Palaeoclimatology,

Palaeoecology. PREPRINT. DOI 10.17605/OSF.IO/9X7DU

Plant tissue forms the base of the soil food web, and alterations in diet quality and/or

251

252

253

254

255

256

257

258

259

260

261

262

263

264

265

266 267 at the K-Pg boundary in Big Bend.

268

269

270

271

272

plant type affects physiological determinants of herbivorous-insect body size (Frajer et al. 1989;

Young et al. 1998; Davidowitz et al. 2004; Smith et al. 2009). Thus, a shift in plant taxa, plant ecological strategies and/or reduction of detrital-plant nutritional value between the Cretaceous and Paleocene could have been a primary driving mechanism for the Lilliput effect in soildwelling organisms. There was a major, abrupt extinction of Cretaceous plant taxa across the KPg boundary, which caused significant changes in plant communities globally (e.g., Vajda and Bercovici 2012; Nichols and Johnson 2008). In the Big Bend area, there is a well-documented, diverse record of late Cretaceous - early Paleocene wood fossils that demonstrates a change from araucariacean conifer dominated fossil wood assemblage in the Javelina Formation to a wood assemblage made up of primarily angiosperm taxa in the Black Peaks Formation, indicating a change in plant communities across the K-Pg boundary (Wheeler et al. 1994; Wheeler and Lehman 2000, 2005, 2009; Lehman and Wheeler 2001; Manchester et al. 2010). However, the fossil wood occurrences in the upper Javelina and Black Peaks Formations are restricted to a few stratigraphic intervals that are separated by a significant amount of time (Wheeler and Lehman $2005 ; 2009$ ), and the fossil wood record is only representative of a portion of the total plant community. This limits our ability to assess the full extent of plant extinction and floral turnover

Whereas there is no high-resolution plant record for the K-Pg boundary from the Big Bend area, records from across North America, including from the geographically proximate Raton Basin, document a 30 to $>50 \%$ extinction of plant taxa at the K-Pg boundary followed by a short-lived interval dominated by fern taxa (the "fern spike") and then a prolonged recovery dominated by angiosperms (Vajda and Bercovici 2014, and references therein). When compared 
Wiest, L.A., Lukens, W.E., Peppe, D.J., Driese, S.G., and Tubbs, J., (in press), Terrestrial evidence for the Lilliput effect across the Cretaceous-Paleogene (K-Pg) boundary, Palaeogeography, Palaeoclimatology,

Palaeoecology. PREPRINT. DOI 10.17605/OSF.IO/9X7DU

273 to their Cretaceous counterparts, Paleocene floras were lower in diversity and were dominated by

274 a few species that were geographically widespread (e.g., Wing et al. 1995; Wilf and Johnson

275 2004; Peppe 2010). Given that this pattern has been observed across North America, it is very

276 likely that the Big Bend region experienced a similar extinction of plants and plant community

277 response across the K-Pg boundary. Therefore, we interpret the observed reduction in $\mathrm{D}_{N}$ at

278 Dawson Creek to have occurred contemporaneously with the plant extinction at the K-Pg

279 boundary.

280

In addition to a significant extinction of Cretaceous taxa, there is evidence for a shift in

281 plant ecological strategies across the boundary. A study of fossil leaves from the Williston Basin

282 in North Dakota documents the selective extinction of slow-growing evergreen plant species

283 across the K-Pg boundary, which suggests a fundamental shift in plant ecological strategies

284 towards taxa that favored fast growth strategies with minimized high carbon assimilation rates

285 and low carbon investment (Blonder et al. 2014). Generally, leaves of plants with fast growth

286 strategies are associated with high amounts of insect damage because they are thinner and have

287 higher nutrient content making them more palatable to insect herbivores (e.g., Coley and Barone,

288 1996; Royer et al. 2007; Currano et al. 2008; Wilf 2008). Studies of fossil wood from the Big

289 Bend area indicate Paleocene taxa have notable anatomical changes from Cretaceous taxa, such

290 as an increase in growth rings and a decrease in exclusively scalariform perforation plates

291 (Wheeler and Lehman, 2009). This suggests changes in the ecological strategies of at least some

292 tree species between the Cretaceous and Paleocene.

293

The combination of a major plant extinction and a shift in plant ecological strategies

294 across the K-Pg boundary would have caused fundamental alterations in the diet of the N. bowni

295 tracemakers. Thus, we hypothesize that the dramatic plant-community shifts in taxonomic 
Wiest, L.A., Lukens, W.E., Peppe, D.J., Driese, S.G., and Tubbs, J., (in press), Terrestrial evidence for the Lilliput effect across the Cretaceous-Paleogene (K-Pg) boundary, Palaeogeography, Palaeoclimatology,

Palaeoecology. PREPRINT. DOI 10.17605/OSF.IO/9X7DU

composition and ecological strategies that occurred at the K-Pg boundary were an important forcing mechanism for the observed Lilliput effect in subterranean insects.

The Lilliput effect in $\mathrm{D}_{N}$ documented across the K-Pg boundary could reflect either a reduction in organism body size (phyletic dwarfism) or the replacement of larger-bodied clades with smaller-bodied forms or species that generate morphologically identical structures. Though the insect fossil record is relatively limited, insect damage on fossil leaves is a proxy for insect herbivory, and in turn insect diversity; and therefore, can be used to assess changes in insect diversity and compositional heterogeneity (Carvalho et al. 2014). Analyses of insect damage on Cretaceous and Paleocene floras from the Western Interior of the United States have documented a significant change in insect herbivory, and by extension in insect communities across the K-Pg boundary (e.g., Labandeira et al. 2016 and references therein). Detailed studies of insect damage across the K-Pg boundary in the Williston Basin in North Dakota document a substantial decrease in insect herbivory, a significant decline in intermediate and specialized leaf mines, and a major extinction of leaf-mining insect species at the K-Pg boundary, as well as a significantly unbalanced plant-insect food web in the early Paleocene (Labandeira et al. 2002a, b; Wilf et al. 2006; Donovan et al. 2014). This major insect extinction and community-level change has been hypothesized as a cascading response to the extinctions of Cretaceous host plant species (Labandeira et al. 2002a). Based on these records from North America, it seems reasonable that there was also a significant extinction of insects across the K-Pg boundary in the Big Bend region. Therefore, it is possible that the reduction in body size we document in our trace fossil analyses could reflect an extinction of larger-bodied tracemakers and/or a change in the insect community structure and composition. 
Wiest, L.A., Lukens, W.E., Peppe, D.J., Driese, S.G., and Tubbs, J., (in press), Terrestrial evidence for the Lilliput effect across the Cretaceous-Paleogene (K-Pg) boundary, Palaeogeography, Palaeoclimatology,

Palaeoecology. PREPRINT. DOI 10.17605/OSF.IO/9X7DU

\subsection{Stratigraphic position of the K-Pg boundary within the Dawson Creek section}

There is currently no definitive age control on P22-P28, except that this conformable succession of stacked paleosols occurs between Maastrichtian fauna ( 172 m; Fig. 2) and early Paleocene fauna ( 195 m; Lawson 1972, 1975; Lehman 1985, 1990; Standhardt 1986; Schiebout et al. 1987). It is possible that the K-Pg boundary occurs at the unconformity surface immediately superjacent to P28. If this is the case, this entire dataset and interpreted environmental disturbance would have occurred prior to the K-Pg event sometime within chron 29r. However, this interpretation is very unlikely based on the reversed polarity of the sequence, the occurrence of the Late Maastrichtian Event (LME) in P19, and sedimentation-rate calculations based on magnetostratigraphy and pedogenesis (Nordt et al. 2003; Leslie et al. accepted). Therefore, we agree with the existing interpretations that the chronostratigraphic K-Pg boundary is at or near P23 (Fig. 2; e.g., Lehman 1990; Nordt et al. 2003; Atchley et al. 2004; Lehman and Busby 2007; Cobb 2016; Leslie et al. accepted). Trace-fossil analysis has been demonstrated previously as an effective tool for refining the sedimentological history and stratigraphic relationships at other K-Pg exposures (Ekdale and Bromley 1984; Savrda 1993; Ekdale and Stinnesbeck 1998; Twitchett and Barras 2004; Rodríguez-Tovar et al. 2004, 2010, 2016; Rodríguez-Tovar 2005; Chin et al. 2013; Sosa-Montes de Oca et al. 2013, 2016; Horner et al. 2016). Thus, in the absence of diagnostic K-Pg boundary indicators, we propose that the trace fossil dataset herein can be used to refine the stratigraphic position of the K-Pg event in the Dawson Creek section. Our ichnological proxy indicates a significant reduction in tracemaker body size in P22, which is like patterns seen across other KPg boundary sections in North America and Europe (e.g., Wiest et al. 2015, 2016; Łaska et al. 2017). Based on these results, we interpret the trace fossils within P22 to represent a post-event 
Wiest, L.A., Lukens, W.E., Peppe, D.J., Driese, S.G., and Tubbs, J., (in press), Terrestrial evidence for the Lilliput effect across the Cretaceous-Paleogene (K-Pg) boundary, Palaeogeography, Palaeoclimatology,

Palaeoecology. PREPRINT. DOI 10.17605/OSF.IO/9X7DU

342 recovery community, stratigraphically above the K-Pg transition. This implies that the

343 chronostratigraphic boundary is associated with the channel-sand body containing reworked

344 pterosaur remains just below P22 ( 172 m; Fig. 2; Lehman 1990). Thus, we posit that the

345 apparent absence of extraterrestrial-impact indicators at this site (e.g., Lehman, 1990) is

346 potentially attributed to widespread erosion that occurred contemporaneous with, or shortly after,

347 the K-Pg event. Current and ongoing advancements in absolute dating of sandstones may permit

348 further testing of this hypothesized placement of the stratigraphic K-Pg boundary in the future.

5.4 Is there a common forcing mechanism?

Each of the studies that have documented the Lilliput effect across the K-Pg boundary

352 thus far have provided rationale for marine-environmental mechanisms that could have

353 potentially driven the phenomenon for that particular type of taxon. It has been demonstrated that

354 planktic foraminifera can experience the Lilliput effect from a diverse range of stressors

355 including greenhouse warming, anoxia/dysoxia, restricted basins, and volcanism (Keller 2003;

356 Keller and Abramovich 2009). The dwarfism of some coccolithophore species during the earliest

357 Paleocene is attributed to unfavorable environmental conditions such as anomalous fluctuations

358 in primary productivity and poor stratification of surface waters (Gardin and Monechi 1998).

359 Aberhan et al. (2007) found that the most likely explanation for a reduction in body size within

360 mollusk-dominated benthic shelf ecosystems is a reduction in nutrient availability associated

361 with the decline in primary production. Likewise, dwarfism of marine vermiform organisms has

362 also been attributed to limited food supply associated with a collapse of the food web in the latter

363 stages of the extinction event (Hsü and McKenzie 1985; Hansen et al. 1993; Laska et al. 2017).

364 The reduction of body size of infaunal crustaceans from diverse, widespread shallow-marine 
Wiest, L.A., Lukens, W.E., Peppe, D.J., Driese, S.G., and Tubbs, J., (in press), Terrestrial evidence for the Lilliput effect across the Cretaceous-Paleogene (K-Pg) boundary, Palaeogeography, Palaeoclimatology,

Palaeoecology. PREPRINT. DOI 10.17605/OSF.IO/9X7DU

365 environments is most likely attributed to either a decrease in oxygen availability following the

366 extinction event (Savrda et al. 1984; Ekdale 1985; Savrda and Bottjer 1987a, 1987b; Wiest et al.

367 2015), a restricted nutrient supply, or a combination of these factors (Wiest et al. 2016; Łaska et

368 al. 2017; Rodríguez-Tovar et al. 2017). In addition to bony fish, lamniform sharks, which were

369 apex marine predators across the K-Pg transition, also experienced the Lilliput effect (Belben et

370 al. 2017). This phenomenon, as evidenced by quantitative shark-tooth morphometrics, is

371 attributed to taxonomic turnover, as well as major shifts in ecological function, such as changes

372 in the available prey and/or dietary preference of the sharks (Belben et al. 2017).

373 There does not appear to be an unambiguous, all-encompassing explanation to account

374 for this widespread phenomenon, but it does seem to be a universal response to different

375 components of a complex, interrelated disruption of the food web. Likewise, the driving

376 mechanism for the reported body-size decrease in terrestrial $N$. bowni tracemakers is seemingly a

377 combination of the Cretaceous plant extinctions and a shift in plant ecological strategies across

378 the K-Pg boundary, which would have caused fundamental alterations in the diet of the

379 herbivorous, subterranean insects.

\section{Conclusions}

The addition of terrestrial evidence for the Lilliput effect in response to the K-Pg event

382 indicates that this phenomenon affected diverse biota across highly disparate ecosystems. Future

383 studies should focus on extending such datasets across different taxa and depositional

384 environments, particularly from the continental realm, to better understand the spatial, temporal,

385 and ecological context of the Lilliput effect as it relates to the response and recovery of the end-

386 Cretaceous mass extinction. Trace fossils have great potential to yield such an archive because 
Wiest, L.A., Lukens, W.E., Peppe, D.J., Driese, S.G., and Tubbs, J., (in press), Terrestrial evidence for the Lilliput effect across the Cretaceous-Paleogene (K-Pg) boundary, Palaeogeography, Palaeoclimatology, Palaeoecology. PREPRINT. DOI 10.17605/OSF.IO/9X7DU

387 they are commonly preserved in a variety of settings, are generated by a wide range of organisms, and often occur in numbers sufficient for statistical analysis.

\section{Acknowledgments}

Caitlin Leslie and Stacy Atchley kindly assisted with locating the previously described

Dawson Creek stratigraphy. We thank Yohan Letourmy for assisting in the field. We appreciate

Steve Forman, Rena Bonem, Elizabeth Wheeler, and Steve Hasiotis for providing discussions

and feedback. Conrad Labandeira, Jon Smith, and an anonymous reviewer are thanked for

helpful comments on an earlier draft. Funding for this project was provided by an SEPM

Foundation grant awarded to L.A.W. This research was completed under NPS Permit \# BIBE-

397 2015-SCI-0012.

398

\section{References}

Aberhan, M., Weidemeyer, S., Kiessling, W., Scasso, R.A., Medina, F.A., 2007. Faunal evidence for reduced productivity and uncoordinated recovery in Southern Hemisphere Cretaceous-Paleogene boundary sections. Geology, 35(3), 227-230. stratigraphy: A possible example from the Cretaceous-Tertiary transition of the Tornillo 74(3), 391-404.

Atkinson, D., 1994. Temperature and organism size: a biological law for ectotherms? Advances in Ecological Research, 25, 1-1. 
Wiest, L.A., Lukens, W.E., Peppe, D.J., Driese, S.G., and Tubbs, J., (in press), Terrestrial evidence for the Lilliput effect across the Cretaceous-Paleogene (K-Pg) boundary, Palaeogeography, Palaeoclimatology,

Palaeoecology. PREPRINT. DOI 10.17605/OSF.IO/9X7DU

Bardeen, C.G., Garcia, R.R., Toon, O.B., Conley, A.J., 2017. On transient climate change at the Cretaceous-Paleogene boundary due to atmospheric soot injections. Proceedings of the National Academy of Sciences, 201708980.

Belben, R.A., Underwood, C.J., Johanson, Z., Twitchett, R.J., 2017. Ecological impact of the end-Cretaceous extinction on lamniform sharks. PLoS One, 12(6), e0178294.

Beyrouty, C.A., Keino, J.K., Gbur, E.E., Hanson, M.G., 2000. Phytotoxic concentrations of subsoil aluminum as influenced by soils and landscape position: Soil Science, 165(2), 135-143.

Blonder, B., Royer, D. L., Johnson, K. R., Miller, I., Enquist, B. J., 2014, Plant ecological strategies shift across the Cretaceous-Paleogene boundary: PLoS Biol, 12(9), e1001949.

Bottjer, D.J., Droser, M.L., 1994. The history of Phanerozoic bioturbation. In: Donovan, S.K. (Ed.), The Paleobiology of Trace Fossils. John Hopkins, Baltimore, 155-176.

Bown, T.M., Kraus, M.J., 1983. Ichnofossils of the alluvial Willwood Formation (lower Eocene), Bighorn Basin, northwest Wyoming, USA. Palaeogeography, Palaeoclimatology, Palaeoecology, 43(1-2), 95-128.

Carvalho, M. R., Wilf, P., Barrios, H., Windsor, D. M., Currano, E. D., Labandeira, C. C., Jaramillo, C. A., 2014, Insect leaf-chewing damage tracks herbivore richness in modern and ancient forests: PloS one, 9(5), e94950.

Cheung, W.W., Sarmiento, J.L., Dunne, J., Frölicher, T.L., Lam, V.W., Palomares, M.D., Watson, R., Pauly, D., 2013. Shrinking of fishes exacerbates impacts of global ocean changes on marine ecosystems. Nature Climate Change, 3(3), 254. 
Wiest, L.A., Lukens, W.E., Peppe, D.J., Driese, S.G., and Tubbs, J., (in press), Terrestrial evidence for the Lilliput effect across the Cretaceous-Paleogene (K-Pg) boundary, Palaeogeography, Palaeoclimatology,

Palaeoecology. PREPRINT. DOI 10.17605/OSF.IO/9X7DU

Chin, K., Pearson, D., Ekdale, A.A., 2013. Fossil worm burrows reveal very early terrestrial animal activity and shed light on trophic resources after the end-Cretaceous mass extinction. PLoS One, 8(8), e70920.

Cobb, J., 2016, Sedimentology of the Cretaceous-Paleogene boundary interval in the Tornillo Group of West Texas [M.S. thesis]: Lubbock, Texas Tech University, (163 pp.)

Coley, P. D., Barone, J. A., 1996, Herbivory and plant defenses in tropical forests: Annual Review of Ecology and Systematics, 27(1), 305-335.

Counts, J.W., Hasiotis, S.T., 2009. Neoichnological experiments with masked chafer beetles (Coleoptera: Scarabaeidae): implications for backfilled continental trace fossils. PALAIOS, 24(2), 74-91.

Currano, E. D., Wilf, P., Wing, S. L., Labandeira, C. C., Lovelock, E. C., Royer, D. L., 2008, Sharply increased insect herbivory during the Paleocene-Eocene thermal maximum: Proceedings of the National Academy of Sciences of the United States of America, 105(6), 1960-1964.

Davidowitz, G., D’Amico, L.J., Nijhout, H.F., 2004. The effects of environmental variation on a mechanism that controls insect body size. Evolutionary Ecology Research, 6(1), 49-62.

Delhaize, E., Ryan, P.R., 1995. Aluminum toxicity and tolerance in plants. Plant Physiology, 107(2), 315 .

Donovan, M. P., Wilf, P., Labandeira, C. C., Johnson, K. R., Peppe, D. J., 2014, Novel insect leaf-mining after the end-Cretaceous extinction and the demise of Cretaceous leaf miners, Great Plains, USA: PloS one, 9(7), e103542. 
Wiest, L.A., Lukens, W.E., Peppe, D.J., Driese, S.G., and Tubbs, J., (in press), Terrestrial evidence for the Lilliput effect across the Cretaceous-Paleogene (K-Pg) boundary, Palaeogeography, Palaeoclimatology,

Palaeoecology. PREPRINT. DOI 10.17605/OSF.IO/9X7DU

451 Driese, S.G., Mora, C.I., Elick, J.M., 1997. Morphology and taphonomy of root and stump casts

452

453

454

455

456

457

458

459

460

461

462

463

464

465

466

467

468

469

470

471 of the earliest trees (Middle to Late Devonian), Pennsylvania and New York, USA.

PALAIOS, 12(6), 524-537.

Droser, M.L., Bottjer, D.J., 1986. A semiquantitative field classification of ichnofabric. Journal of Sedimentary Petrology 56, 558-559.

Ekdale, A.A., Bromley, R.G., 1984. Sedimentology and ichnology of the Cretaceous-Tertiary boundary in Denmark: implications for the causes of the terminal Cretaceous extinction. Journal of Sedimentary Petrology 54, 681-703.

Ekdale, A.A., 1985. Paleoecology of the marine endobenthos. Palaeogeography, Palaeoclimatology, Palaeoecology, 50(1), 63-81.

Ekdale, A.A., Stinnesbeck, W., 1998. Trace fossils in Cretaceous-Tertiary (KT) boundary beds in northeastern Mexico: implications for sedimentation during the KT boundary event. PALAIOS, 13, 593-602.

Elick, J.M., Driese, S.G., Mora, C.I., 1998. Very large plant and root traces from the Early to Middle Devonian: Implications for early terrestrial ecosystems and atmospheric $\mathrm{p}\left(\mathrm{CO}_{2}\right)$. Geology, 26(2), 143-146.

Feng, Z., Wang, J., Rößler, R., Ślipiński, A., Labandeira, C., 2017. Late Permian wood-borings reveal an intricate network of ecological relationships. Nature Communications, 8(1), 556.

Frajer, E.D., Bowers, M.D., Bazzaz, F.A., 1989. The effects of enriched carbon dioxide atmospheres on plant-insect herbivore interactions. Science, 243(4895), 1198-1201. 
Wiest, L.A., Lukens, W.E., Peppe, D.J., Driese, S.G., and Tubbs, J., (in press), Terrestrial evidence for the Lilliput effect across the Cretaceous-Paleogene (K-Pg) boundary, Palaeogeography, Palaeoclimatology, Palaeoecology. PREPRINT. DOI 10.17605/OSF.IO/9X7DU

472 Gallagher, W.B., 1990. Biostratigraphy and paleoecology of the Upper Cretaceous-Lower

473

474

475

476

477

478

479

480

481

482

483

484

485

486

487

488

489

490

491

492

493

494
Tertiary sequence in the New Jersey Coastal Plain: Ph.D. Dissertation, University of Pennsylvania, Philadelphia, (402 pp.)

Gardin, S., Monechi, S., 1998. Palaeoecological change in middle to low latitude calcareous nannoplankton at the Cretaceous/Tertiary boundary. Bulletin de la Société Géologique de France, 169(5), 709-723.

Genise, J.F., 2017. Ichnoentomology: insect traces in soils and paleosols. Topics in Geobiology, 37, Springer, (694 pp.)

Genise, J.F., Bellosi, E.S., Gonzalez, M.G., 2004. An approach to the description and interpretation of ichnofabrics in palaeosols. Geological Society, London, Special Publications, 228(1), 355-382.

Grimaldi, D., Engel, M.S., 2005. Evolution of the Insects. Cambridge University Press.

Hansen, T.A., Farrell, B.R., Upshaw, B., 1993. The first 2 million years after the CretaceousTertiary boundary in east Texas: rate and paleoecology of the molluscan recovery. Paleobiology, 19(2), 251-265.

Harries, P.J., Kauffman, E.G., Hansen, T.A., 1996. Models for biotic survival following mass extinction. In: Hart, M.B. (Ed.), Biotic Recovery from Mass Extinction Events. The Geological Society, London Special Publication, 102, 41-60.

Harries, P.J., Knorr, P.O., 2009. What does the 'Lilliput Effect'mean?. Palaeogeography, Palaeoclimatology, Palaeoecology, 284(1), 4-10.

Hasiotis, S.T., Bown, T.M., 1992, Invertebrate trace fossils: The backbone of continental ichnology. In: Maples, C.G., West, R.R. (Eds.), Trace Fossils. Short Courses in Paleontology, 5, 64-104. 
Wiest, L.A., Lukens, W.E., Peppe, D.J., Driese, S.G., and Tubbs, J., (in press), Terrestrial evidence for the Lilliput effect across the Cretaceous-Paleogene (K-Pg) boundary, Palaeogeography, Palaeoclimatology,

Palaeoecology. PREPRINT. DOI 10.17605/OSF.IO/9X7DU

Hasiotis, S.T., 2002. Continental Trace Fossils. SEPM, Short Course Notes Number 51, Tulsa, Oklahoma, (134 pp.)

Hembree, D.I., Blair, M.G., 2016. A paleopedological and ichnological approach to interpreting spatial and temporal variability in Early Permian fluvial deposits of the lower Dunkard Group, West Virginia, USA. Palaeogeography, Palaeoclimatology, Palaeoecology, 454, 246-266.

Horner, R.J., Wiest, L.A., Buynevich, I.V., Terry, D.O., Grandstaff, D.E., 2016. Chemical composition of Thalassinoides boxwork across the marine $\mathrm{K}-\mathrm{Pg}$ boundary of central New Jersey, USA. Journal of Sedimentary Research, 86(12), 1444-1455.

Hsü, K.J., McKenzie, J.A., 1985. A "Strangelove" ocean in the earliest Tertiary. In: Sundquist, E.T., Broecker, W.S. (Eds.), The carbon cycle and atmospheric C02: Natural variations Archean to present: Washington, D.C., American Geophysical Union, 487-492.

Keller, G., 2003. Biotic effects of impacts and volcanism. Earth and Planetary Science Letters, 215(1), 249-264.

Keller, G., Abramovich, S., 2009. Lilliput effect in late Maastrichtian planktic foraminifera: Response to environmental stress. Palaeogeography, Palaeoclimatology, Palaeoecology, 284(1), 47-62.

Labandeira, C. C., Johnson, K. R., Wilf, P., 2002a, Impact of the terminal Cretaceous event on plant-insect associations: Proceedings of the National Academy of Sciences of the United States of America, 99(4), 2061-2066.

Labandeira, C. C., Johnson, K. R., Lang, P., 2002b, Preliminary assessment of insect herbivory across the Cretaceous-Tertiary boundary: Major extinction and minimum rebound. In: Hartman, J. H., Johnson, K. R., Nichols, D. J. (Eds.), The Hell-Creek Formation and the 
Wiest, L.A., Lukens, W.E., Peppe, D.J., Driese, S.G., and Tubbs, J., (in press), Terrestrial evidence for the Lilliput effect across the Cretaceous-Paleogene (K-Pg) boundary, Palaeogeography, Palaeoclimatology,

Palaeoecology. PREPRINT. DOI 10.17605/OSF.IO/9X7DU

Cretaceous-Tertiary boundary in the northern Great Plains: An integrated continental record of the end of the Cretaceous: Boulder, Colorado, Geological Society of America Special Paper 361, 297-328.

Labandeira, C.C., Rodríguez-Tovar, F.J., Uchman, A., 2016. The End-Cretaceous Extinction and Ecosystem Change. In: Mángano, M.G., Buatois, L.A. (Eds.), The Trace-Fossil Record of Major Evolutionary Events, Topics in Geobiology 40, Springer, Netherlands, 265-300.

Łaska, W., Rodríguez-Tovar, F.J., Uchman, A., 2017. Evaluating macrobenthic response to the Cretaceous-Palaeogene event: A high-resolution ichnological approach at the Agost section (SE Spain). Cretaceous Research, 70, 96-110.

Lawson, D.A., 1972, Paleoecology of the Tornillo Formation, Big Bend National Park, Brewster County, Texas [M.A. thesis]: Austin, University of Texas, (182 pp.)

Lawson, D.A., 1975. Pterosaur from the latest Cretaceous of West Texas: discovery of the largest flying creature. Science, 187(4180), 947-948.

Lefebvre, F., Nel, A., Papier, F., Grauvogel-Stamm, L., Gall, J.C., 1998. The first 'cicada-like Homoptera' from the Triassic of the Vosges, France. Palaeontology, 41(6), 1195-1200.

Lehman, T.M., 1985. Stratigraphy, sedimentology, and paleontology of Upper Cretaceous (Campanian-Maastrichtian) sedimentary rocks in Trans-Pecos Texas [Doctoral dissertation], Austin, University of Texas, (299 pp.)

Lehman, T.M., 1990. Paleosols and the Cretaceous/Tertiary transition in the Big Bend region of Texas. Geology, 18(4), 362-364.

Lehman, T.M., 1991. Sedimentation and tectonism in the Laramide Tornillo Basin of West Texas. Sedimentary Geology, 75(1), 9-28. 
Wiest, L.A., Lukens, W.E., Peppe, D.J., Driese, S.G., and Tubbs, J., (in press), Terrestrial evidence for the Lilliput effect across the Cretaceous-Paleogene (K-Pg) boundary, Palaeogeography, Palaeoclimatology,

Palaeoecology. PREPRINT. DOI 10.17605/OSF.IO/9X7DU

Lehman, T.M., Busbey, A.B., 2007. Big Bend Field Trip Guidebook. Society of Vertebrate Paleontology, 67th Annual Meeting, Field Trip Guidebook, (69 pp.)

Lehman, T.M., Wheeler, E.A., 2001. Fossil dicotyledonous forest from the Upper Cretaceous of Big Bend National Park, Texas. Palaios 16: 102-108.

Leslie, C.E., Peppe, D.J., Williamson, T.E., Heizler, M., Atchley, S.C., Nordt, L., Standhardt, B., accepted. Revised age constraints for Late Cretaceous to early Paleocene strata, Dawson Creek section, Big Bend National Park, west Texas. Geological Society of America Bulletin.

Leslie. C.E., Peppe, D.J., Atchley, S.C., Williamson, T.E., Heizler, M., Nordt, L., 2015. Revised age constraints for Late Cretaceous to early Paleocene strata from the Dawson Creek section, Big Bend National Park, west Texas, USA. Journal of Vertebrate Paleontology, Program and Abstracts, 2015, 162.

Manchester, S.R., Lehman, T.M., Wheeler, E.A. 2010. Fossil palms (Arecaceae, Coryphoideae) associated with juvenile herbivorous dinosaurs in the Upper Cretaceous Aguja formation, Big Bend National Park, Texas. International Journal of Plant Sciences, 171(6): 679-689. Marlatt, C.L., 1907. The periodical cicada. United States Department of Agriculture Bureau of Entomology Bulletin. 71, (181 pp.)

Martínez-Díaz, J.L., Phillips, G.E., Nyborg, T., Espinosa, B., de Araújo Távora, V., CentenoGarcía, E., Vega, F.J., 2016. Lilliput effect in a retroplumid crab (Crustacea: Decapoda) across the K/Pg boundary. Journal of South American Earth Sciences, 69, 11-24.

Martínez-Díaz, J.L., Aguillón-Martínez, M.C., Luque, J., Vega, F.J., 2017. Paleocene decapod Crustacea from northeastern Mexico: Additions to biostratigraphy and diversity. Journal of South American Earth Sciences, 74, 7-82. 
Wiest, L.A., Lukens, W.E., Peppe, D.J., Driese, S.G., and Tubbs, J., (in press), Terrestrial evidence for the Lilliput effect across the Cretaceous-Paleogene (K-Pg) boundary, Palaeogeography, Palaeoclimatology,

Palaeoecology. PREPRINT. DOI 10.17605/OSF.IO/9X7DU

Morrow, J.R., Hasiotis, S.T., 2007. Infaunal response through mass-extinction episodes: predictive models and observed patterns. In: Miller, W. III, (Ed.), Trace FossilsConcepts, Problems, Prospects. Elsevier Press, 575-598.

Nichols, D. J., Johnson, K. R., 2008, Plants and the K-Pg boundary, Cambridge, Cambridge University Press, (280 pp.)

Nordt, L., Atchley, S., Dworkin, S., 2003. Terrestrial evidence for two greenhouse events in the latest Cretaceous. GSA today, 13(12), 4-9.

Nordt, L., Dworkin, S.I., Atchley, S.C., 2011. Ecosystem response to soil biogeochemical behavior during the Late Cretaceous and early Paleocene within the western interior of North America. GSA Bulletin, 123 (9-10): 1745-1762.

Parmesan, C., 2006. Ecological and evolutionary responses to recent climate change. Annu. Rev. Ecol. Evol. Syst., 37, 637-669.

Peppe, D. J., 2010, Megafloral change in the early and middle Paleocene in the Williston Basin, North Dakota, USA: Palaeogeography, Palaeoclimatology, Palaeoecology, 298(3-4), 224234.

Qadir, M., Schubert, S., 2002. Degradation processes and nutrient constraints in sodic soils. Land Degradation \& Development, 13(4), 275-294.

Rapp, S.D., MacFadden, B.J., Schiebout, J.A., 1983. Magnetic polarity stratigraphy of the early Tertiary Black Peaks Formation, Big Bend National Park, Texas. The Journal of Geology, 91(5), 555-572.

Rasnitsyn, A.P., Quicke, D.L.J., 2002. History of Insects: Kluwer Academic Publishers, Norwell, Massachusetts, (517 pp.) 
Wiest, L.A., Lukens, W.E., Peppe, D.J., Driese, S.G., and Tubbs, J., (in press), Terrestrial evidence for the Lilliput effect across the Cretaceous-Paleogene (K-Pg) boundary, Palaeogeography, Palaeoclimatology, Palaeoecology. PREPRINT. DOI 10.17605/OSF.IO/9X7DU

605 06

Retallack, G.J., 1988. Field recognition of paleosols. Geological Society of America Special Papers, 216, 1-20.

Robertson, D.S., McKenna, M.C., Toon, O.B., Hope, S., Lillegraven, J.A., 2004. Survival in the first hours of the Cenozoic. Geological Society of America Bulletin 116(5-6), 760-768.

Rodríguez-Tovar, F.J., 2005, Fe-oxide spherules infilling Thalassinoides burrows at the Cretaceous-Paleogene (K-P) boundary; evidence of near-contemporaneous macrobenthic colonization during the K-P event: Geology, 33, 585-588.

Rodríguez-Tovar, F.J., 2007. Substrate firmness controlling nesting behavior of Bembix oculata (Hymenoptera, Bembicinae). In: Bromley R.G., Buatois, L.A., Mángano, M.G., Genise, J.F. and Melchor, R.N., (Eds.), Sedimentorganism Interactions: A Multifaceted Ichnology. SEPM Special Publication, 88, 353-359.

Rodríguez-Tovar, F.J., Martínez-Ruiz, F., Bernasconi, S.M., 2004, Carbon isotope evidence for the timing of the Cretaceous-Palaeogene macrobenthic colonization at the Agost section (southeast Spain): Palaeogeography, Palaeoclimatology, Palaeoecology, 203, 65-72.

Rodríguez-Tovar, F.J., Miguez-Salas, O. and Duarte, L.V., 2017. Toarcian Oceanic Anoxic Event induced unusual behaviour and palaeobiological changes in Thalassinoides tracemakers. Palaeogeography, Palaeoclimatology, Palaeoecology, 485, 46-56.

Rodríguez-Tovar, F.J., Uchman, A., Molina, E., Monechi, S., 2010, Bioturbational redistribution of Danian calcareous nannofossils in the uppermost Maastrichtian across the $\mathrm{K}-\mathrm{Pg}$ boundary at Bidart, SW France: Geobios, 43, 569-579. 
Wiest, L.A., Lukens, W.E., Peppe, D.J., Driese, S.G., and Tubbs, J., (in press), Terrestrial evidence for the Lilliput effect across the Cretaceous-Paleogene (K-Pg) boundary, Palaeogeography, Palaeoclimatology,

Palaeoecology. PREPRINT. DOI 10.17605/OSF.IO/9X7DU

607

608

609

610

611

612

613

614

615

616

617

618

619

620

621

622

623

624

625

626

627

628

Rodríguez-Tovar, F.J., Uchman, A., M'Hamdi, A., Riahi, S., Ismail-Lattrache, K.B., 2016.

Ichnological record of palaeoenvironment from the Cretaceous-Paleogene boundary interval at El Kef, Tunisia: The first study of old and new sections at the stratotype area. Journal of African Earth Sciences, 120, 23-30.

Royer, D. L., Sack, L., Wilf, P., Lusk, C. H., Jordan, G. J., Niinemets, Ü., Wright, I. J., Westoby, M., Cariglino, B., Coley, P. D., Cutter, A. D., Johnson, K. R., Labandeira, C. C., Moles, A. T., Palmer, M. B., Valladares, F., 2007, Fossil leaf economics quantified: calibration, Eocene case study, and implications: Paleobiology, 33(4), 574-589.

Savrda, C.E., 1993, Ichnosedimentologic evidence for a noncatastrophic origin of CretaceousTertiary boundary sand in Alabama: Geology, 21, 1075-1078.

Savrda, C.E., Bottjer, D.J., Gorsline, D.S., 1984. Development of a comprehensive oxygendeficient marine biofacies model: evidence from Santa Monica, San Pedro, and Santa Barbara Basins, California Continental Borderland. AAPG Bulletin, 68(9), 1179-1192.

Savrda, C.E., Bottjer, D.J., 1987a. The exaerobic zone, a new oxygen-deficient marine biofacies. Nature, 327(6117), 54-56.

Savrda, C.E., Bottjer, D.J., 1987b. Trace fossils as indicators of bottom-water redox conditions in ancient marine environments. In: New concepts in the use of biogenic sedimentary structures for paleoenvironmental interpretation, D. J. Bottjer (Ed.). Society of Economic Paleontologists and Mineralogists, Pacific Section, Volume and Guidebook 52, 3-26. 
Wiest, L.A., Lukens, W.E., Peppe, D.J., Driese, S.G., and Tubbs, J., (in press), Terrestrial evidence for the Lilliput effect across the Cretaceous-Paleogene (K-Pg) boundary, Palaeogeography, Palaeoclimatology,

Palaeoecology. PREPRINT. DOI 10.17605/OSF.IO/9X7DU

Schiebout, J.A., 1974. Vertebrate paleontology and paleoecology of Paleocene Black Peaks Formation, Big Bend National Park, Texas. Texas Memorial Museum Bulletin, 24, 1-88.

Schiebout, J.A., Rigsby, C.A., Rapp, S.D., Hartnell, J.A., Standhardt, B.R., 1987. Stratigraphy of the Cretaceous-Tertiary and Paleocene-Eocene transition rocks of Big Bend National Park, Texas. The Journal of Geology, 95(3), 359-375.

Sheridan, J.A., Bickford, D., 2011. Shrinking body size as an ecological response to climate change. Nature Climate Change, 1(8), 401.

Sibly, R.M., Atkinson, D., 1994. How rearing temperature affects optimal adult size in ectotherms. Functional Ecology, 486-493.

Smith, J.J., Hasiotis, S.T., 2008. Traces and burrowing behaviors of the cicada nymph Cicadetta calliope: Neoichnology and paleoecological significance of extant soil-dwelling insects. PALAIOS, 23(8), 503-513.

Smith, J.J., Hasiotis, S.T., Kraus, M.J., Woody, D.T., 2008. Naktodemasis bowni: new ichnogenus and ichnospecies for adhesive meniscate burrows (AMB), and paleoenvironmental implications, Paleogene Willwood Formation, Bighorn Basin, Wyoming. Journal of Paleontology, 82(2), 267-278.

Smith, J.J., Hasiotis, S.T., Woody, D.T., Kraus, M.J., 2009. Transient dwarfism of soil fauna during the Paleocene-Eocene Thermal Maximum. Proceedings of the National Academy of Science, 106(42), 17655-17660.

Sosa-Montes de Oca, C., Martínez-Ruiz, F., Rodríguez-Tovar, F.J., 2013, Bottom-water conditions in a marine basin after the Cretaceous-Paleogene impact event: timing the recovery of oxygen levels and productivity: PLoS ONE, 8(12), e82242. 
Wiest, L.A., Lukens, W.E., Peppe, D.J., Driese, S.G., and Tubbs, J., (in press), Terrestrial evidence for the Lilliput effect across the Cretaceous-Paleogene (K-Pg) boundary, Palaeogeography, Palaeoclimatology,

Palaeoecology. PREPRINT. DOI 10.17605/OSF.IO/9X7DU

651 Sosa-Montes de Oca, C., Rodríguez-Tovar, F.J., Martínez-Ruiz, F., 2016, Geochemical and

652

653

654

655

656

657

658

659

660

661

662

663

664

665

666

667

668

669

670

671

672 isotopic characterization of trace fossil infillings: new insights on tracemaker activity after the K-Pg impact event. Cretaceous Research, 57, 391-401.

Standhardt, B.R., 1986, Vertebrate paleontology of the Cretaceous/Tertiary transition of Big Bend National Park, Texas [Ph.D. thesis]: Baton Rouge, Louisiana State University, (298 pp.)

Tashiro, H., 1987. Turfgrass insects of the United States and Canada. Cornell University Press. (474 pp.)

Twitchett, R.J., 2007. The Lilliput effect in the aftermath of the end-Permian extinction event. Palaeogeography, Palaeoclimatology, Palaeoecology 252, 132-144.

Twitchett, R.J., Barras, C.G., 2004. Ichnostratigraphy and mass extinctions. In: McIlroy, D., (Ed.), The Application of Ichnology to Paleoenvironmental and Stratigraphic Analysis. The Geological Society, London Special Publication 228, 397-418.

Vajda, V., Bercovici, A., 2012. Palynostratigraphy of the Cretaceous-Paleogene mass-extinction interval of the Southern Hemisphere. Dicéngxué zázhì, 36(2), 153-164.

Vajda, V., Bercovici, A., 2014, The global vegetation pattern across the Cretaceous-Paleogene mass extinction interval: A template for other extinction events: Global and Planetary Change, 122(Supplement C), 29-49.

Vessby, K., 2001. Habitat and weather affect reproduction and size of the dung beetle Aphodius fossor. Ecological Entomology, 26(4), 430-435.

Wheeler, E.A., Lehman, T.A., 2000. Late Cretaceous woody dicots from the Aguja and Javelina Formations, Big Bend National Park, Texas, USA. IAWA Journal, 21, 83-120. 
Wiest, L.A., Lukens, W.E., Peppe, D.J., Driese, S.G., and Tubbs, J., (in press), Terrestrial evidence for the Lilliput effect across the Cretaceous-Paleogene (K-Pg) boundary, Palaeogeography, Palaeoclimatology,

Palaeoecology. PREPRINT. DOI 10.17605/OSF.IO/9X7DU

673 Wheeler, E.A., Lehman, T.M., 2005. Cretaceous-Paleocene conifer woods from Big Bend

674

675

676

677

678

679

680

681

682

683

684

685

686

687

688

689

690

691

692

693

694

695

National Park, Texas. Palaeogeography, Palaeoclimatology, Palaeoecology, 226, 233258.

Wheeler, E.A., Lehman, T.M., 2009. New late Cretaceous and Paleocene dicot woods of Big Bend National Park, Texas and review of Cretaceous wood characteristics. IAWA Journal, 30(3), 293-318.

Wheeler, E.A., Lehman, T.M., Gasson, P.E., 1994. Javelinoxylon, an Upper Cretaceous dicotyledonous tree from Big Bend National Park, Texas, with presumed Malvalean affinities. American Journal of Botany, 81(6), 703-710.

White, J., Strehl, C.E., 1978. Xylem feeding by periodical cicada nymphs on tree roots. Ecological Entomology, 3(4), 323-327.

Wiest, L.A., Buynevich, I.V., 2015, Recent overprinting of Cretaceous-Paleogene Thalassinoides framework. In: McIlroy, D., (Ed.), Ichnology: Papers from Ichnia III: Geological Association of Canada, Miscellaneous Publication 9, 225-230.

Wiest, L.A., Buynevich, I.V., Grandstaff, D.E., Terry, D.O., Maza, Z.A., 2015. Trace fossil evidence suggests widespread dwarfism in response to the end-Cretaceous mass extinction: Braggs, Alabama and Brazos River, Texas. Palaeogeography, Palaeoclimatology, Palaeoecology, 417, 105-111.

Wiest, L.A., Buynevich, I.V., Grandstaff, D.E., Terry, D.O., Jr., Maza, Z., Lacovara, K.J. 2016. Ichnological evidence for endobenthic response to the K-Pg event, New Jersey, U.S.A. PALAIOS, 31, 231-241.

Wilf, P., 2008, Insect-damaged fossil leaves record food web response to ancient climate change and extinction: New Phytologist, 178(3), 486-502. 
Wiest, L.A., Lukens, W.E., Peppe, D.J., Driese, S.G., and Tubbs, J., (in press), Terrestrial evidence for the Lilliput effect across the Cretaceous-Paleogene (K-Pg) boundary, Palaeogeography, Palaeoclimatology,

Palaeoecology. PREPRINT. DOI 10.17605/OSF.IO/9X7DU

696 Wilf, P., Johnson, K. R., 2004, Land plant extinction at the end of the Cretaceous: a quantitative analysis of the North Dakota megafloral record: Paleobiology, 30(3), 347-368.

698

699

700

701

702

703

704

705

706

707

708

709

710

711

712

713

Wilf, P., Labandeira, C. C., Johnson, K. R., Ellis, B., 2006. Decoupled plant and insect diversity after the end-Cretaceous extinction: Science, 313(5790), 1112-1115.

Wilson, J.A., 1970. Vertebrate biostratigraphy of Trans-Pecos Texas. Geologic framework of the Chihuahua Tectonic Belt: Canyon, Texas, West Texas Geological Society, 159-166.

Wing, S. L., Alroy, J., Hickey, L. J., 1995. Plant and mammal diversity in the Paleocene to Early Eocene of the Bighorn Basin: Palaeogeography, Palaeoclimatology, Palaeoecology, 115(1-4), 117-155.

Young, I.M., Blanchart, E., Chenu, C., Dangerfield, M., Fragoso, C., Grimaldi, M., Ingram, J. Monrozier, L.J., 1998. The interaction of soil biota and soil structure under global change. Global Change Biology, 4(7), 703-712. 
Wiest, L.A., Lukens, W.E., Peppe, D.J., Driese, S.G., and Tubbs, J., (in press), Terrestrial evidence for the Lilliput effect across the Cretaceous-Paleogene (K-Pg) boundary, Palaeogeography, Palaeoclimatology, Palaeoecology. PREPRINT. DOI 10.17605/OSF.IO/9X7DU

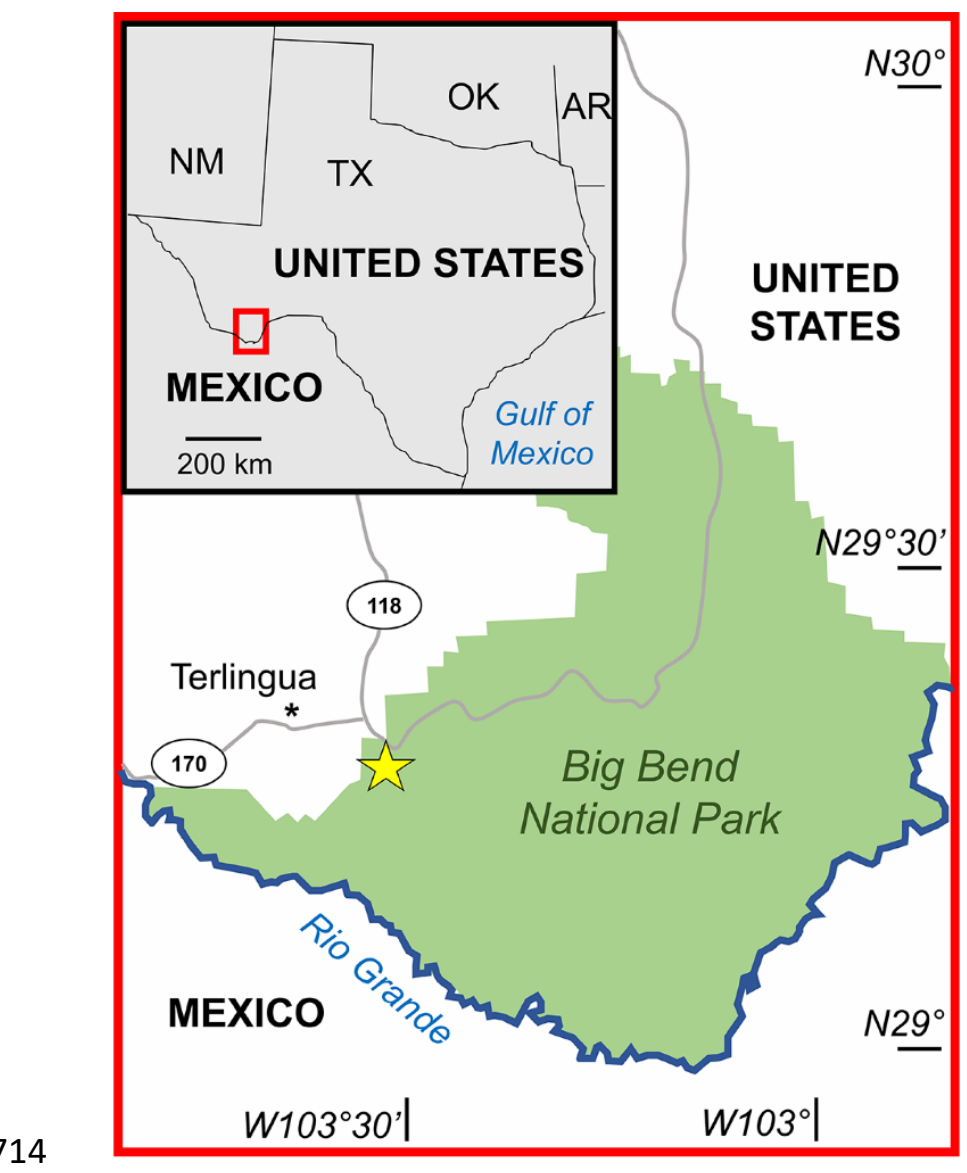

715 Fig. 1. (COLOR USE REQUESTED) Location of Dawson Creek K-Pg section (yellow star)

716 within Big Bend National Park. The red box in the inset indicates the position of the map relative 717 to Texas, U.S.A. 

effect across the Cretaceous-Paleogene (K-Pg) boundary, Palaeogeography, Palaeoclimatology, Palaeoecology. PREPRINT. DOI 10.17605/OSF.IO/9X7DU

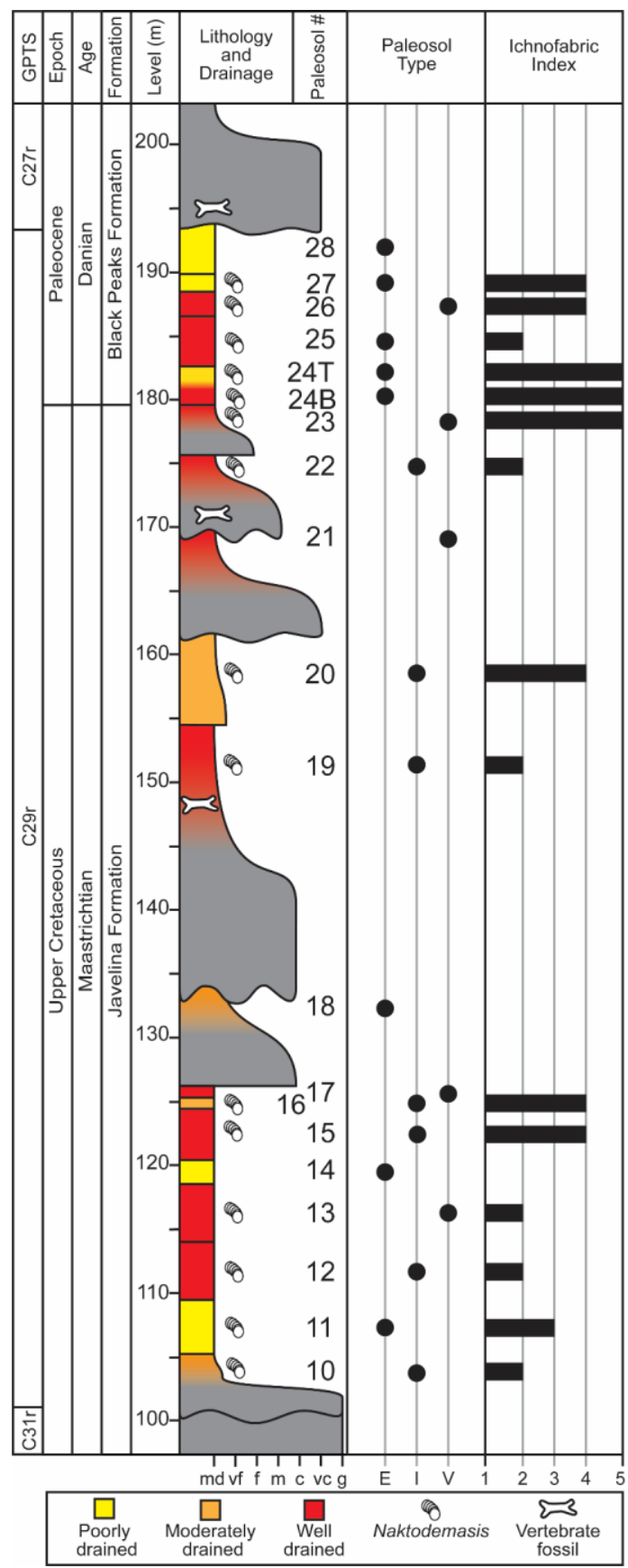

Fig. 2. (COLOR USE REQUESTED) Dawson Creek stratigraphic section modified from Nordt et al. (2003) and Atchley et al. (2004). Paleosol type E = Entisol; I = Inceptisol; V = Vertisol.

722 See section 3 (Methods) for explanation of ichnofabric index values. Geomagnetic Polarity Time 723 Scale (GPTS) data is from Leslie et al. (accepted). 

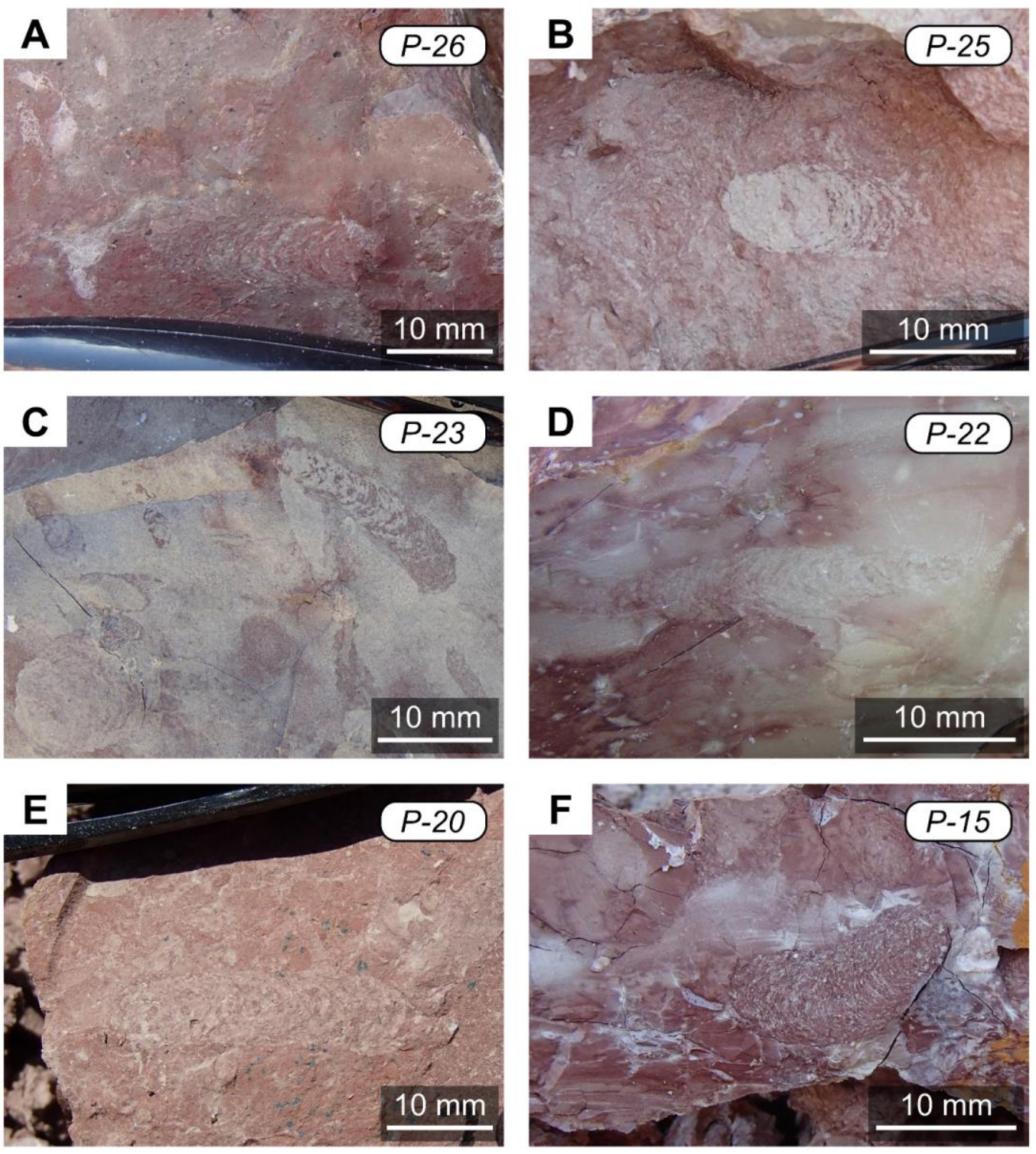

Fig. 3. (COLOR USE REQUESTED) Naktodemasis in pedogenically modified overbank

728 densely spaced meniscate backfill; B) two burrows with differing contrast to P-25 host matrix;

C) multiple backfilled traces in P-23; D) single tunnel from P-22; E) several traces ranging in diameter in an unoriented ped from P-20; F) multiple traces displaying various contrast to P-15. 
Wiest, L.A., Lukens, W.E., Peppe, D.J., Driese, S.G., and Tubbs, J., (in press), Terrestrial evidence for the Lilliput effect across the Cretaceous-Paleogene (K-Pg) boundary, Palaeogeography, Palaeoclimatology, Palaeoecology. PREPRINT. DOI 10.17605/OSF.IO/9X7DU

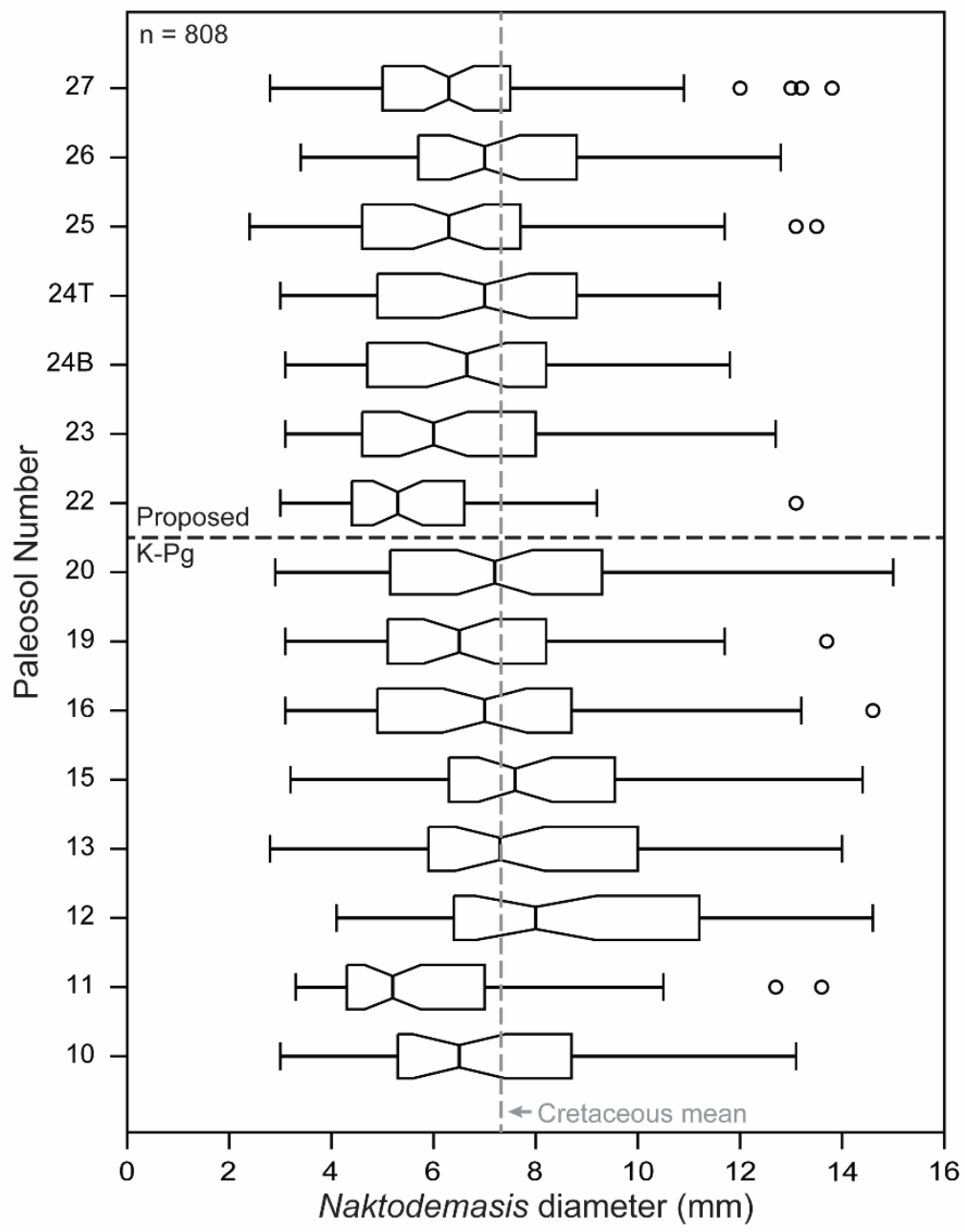

733 Fig. 4. Notched-box plots of Naktodemasis diameter $\left(\mathrm{D}_{N}\right)$ from the Dawson Creek K-Pg section.

734 Notches on the boxes represent the 95\% confidence interval for the mean. See section 5.3 for 735 discussion on $\mathrm{K}-\mathrm{Pg}$ boundary position. 
Wiest, L.A., Lukens, W.E., Peppe, D.J., Driese, S.G., and Tubbs, J., (in press), Terrestrial evidence for the Lilliput effect across the Cretaceous-Paleogene (K-Pg) boundary, Palaeogeography, Palaeoclimatology, Palaeoecology. PREPRINT. DOI 10.17605/OSF.IO/9X7DU

742 Table 1: Summary statistics for $\mathrm{D}_{N}$.

\begin{tabular}{lccccc} 
& Min & Mean & Max & SD & $\mathrm{n}$ \\
\hline Age interval & & & & & \\
$\mathrm{K}$ & 2.8 & 7.3 & 15.0 & 2.7 & 425 \\
$\mathrm{Pg}$ & 2.4 & 6.6 & 13.8 & 2.3 & 383 \\
$\begin{array}{l}\text { Drainage category } \\
\text { Poor }\end{array}$ & 2.8 & 6.4 & 13.8 & 2.4 & 177 \\
Moderate & 2.9 & 7.1 & 15.0 & 2.5 & 218 \\
Well & 2.4 & 7.1 & 14.6 & 2.6 & 413 \\
Paleosol type & & & & & \\
Entisol & 2.4 & 6.5 & 13.8 & 2.4 & 277 \\
Inceptisol & 2.9 & 7.2 & 15.0 & 2.7 & 361 \\
Vertisol & 2.8 & 7.1 & 14.0 & 2.4 & 170 \\
\hline
\end{tabular}

Note: Dimension values are in $\mathrm{mm}$. 